\title{
Guidelines on Developing Community Base Tourism to Sustainable Management of Tourist Attractions
}

\author{
Preechaya Chumsri, Oraphan Chanin, and Pingpis Sriprasert
}

\begin{abstract}
The purpose of this study is to examine factors affecting the processes of developing community based tourism in Thailand and to seek guidelines on strengthening such processes for the sustainable tourism management. The researchers choose to study the community based tourism management in Nakhon Si Thammarat Province. The research instruments are included focus group interviews with community leaders and questionnaires administered around the community tourist attractions. The research findings indicate that key factors which affect the processes of developing community based tourism are economic issues at a moderate level $($ Mean $=3.18$ ), natural resources and environmental management in communities at a moderate level $($ Mean $=3.18)$, health issues at a moderate level $($ Mean $=$ 3.41), religious, culture and tradition issues at a moderate level ( Mean = 3.22), management factors at a moderate level ( Mean = 3.31), safety and security in life and assets at a moderate level ( Mean $=3.49$ ), and an overall view of all individual factors at a moderate level $($ Mean $=3.39)$.
\end{abstract}

Index Terms-Community empowerment, sustainable tourism, and management of tourist attractions.

\section{INTRODUCTION}

Thailand is a country, which has a distinctive point in natural tourism and culture. Additionally, the unique Thai traditional is regarded as a charm that attracts tourists to experience with the atmosphere of places in its country. Nowadays, ecotourism is boosted and supported to be essential element of sustainable development, and also it can be used as a tool or measure in order to promote conservation of biological resources, which incline to decrease and degenerate owing to the development of economy and social of country [1].

Ecotourism has a form of administration and management, which needs permanency. It is necessary to have a systematic plan for a short-term, mid-term and longterm to be the same as other administrations, irrespective of community, local administration, central administration joined with the private organisation as well as the stakeholders of tourism in each places, which all those places are based on the correct mutual data, together with the integration of joined opinion [2].

The community based tourism (CBT) in particular, is one among other tools promoting collective activity in the community as a mean to encourage local people to work

Manuscript received November 10, 2013; revised January 16, 2014.

Preechaya Chumsri and Oraphan Chanin are with the Rajamangala University of Technology Srivijaya, Thailand (e-mail: chayamook@hotmail.com).

Pingpis Sriprasert is with the Nakhon $\mathrm{Si}$ Thammarat Rajabhat University, Thailand. together as a team for economic self-help and social benefits. Therefore, the success of CBT is highly needed in the local community. There is substantial evidence that participation of people are playing a crucial role in small business success. Hence, the objective of this study is to examine the effect between marketing mix and success of CBT at Nakhon Si Thammarat, Thailand.

The researchers who are interested in the study of the methodology to strengthen the tourist attractions by the community will be able totalise the outcome of this research to develop the administration and management of the tourist attractions to be successful.

\section{LITERATURE REVIEW}

The development of community based tourism reinforcing the community is the way that the local community tourist management, which is capable of acquiring attention from many departments. In addition, good planning and well tourism management can generate revenue to the local people, and it can culminate in having a well development in the other ways. Furthermore, it allows people to learn how to work together between local and community. In this regard, it can be counted as one of the methods that can strengthen the local community. The researchers hereby study by making use of the principle of management to help strengthen to the community [2].

\section{A. Definition of Tourism}

Tourism is one of the most important and expanding sectors of the world economy. It is also a major source of foreign exchange earnings for many developing countries. Tourism, because it has become such a large industry, has many impacts which can be felt and seen worldwide and that effect all forms of life. The effects of these impacts can be advantageous but they can also cause many disadvantages and bring many problems with them. If tourism is managed properly (sustainable tourism), however, it can increase the benefits for or positive impacts on the social and natural environment of an area and reduce the negative effects significantly [3]. Tourism is defined by as follows:

"Tourism comprises the activities of persons travelling to and staying in places outside their usual environment for not more than one consecutive year for leisure, business and other purposes not related to the exercise of an activity remunerated from within the place visited. Tourism is different from travel. In order for tourism to happen, there must be a displacement: an individual has to travel, using any type of means of transportation (he might even travel on foot: nowadays, it is often the case for poorer societies, and happens even in more developed ones, and concerns 
pilgrims, hikers). But all travel is not tourism" [4].

\section{B. Sustainable Tourism}

Sustainable tourism is a result of sustainable tourism development, a development a process. Sustainable tourism is not in itself a unique form of tourism as is for example adventure tourism, but a philosophy and a set of guidelines which can be used as a frame-work when developing all types of tourism, independent of scale and type, towards sustainability [6]. The concept of sustainable tourism was developed to achieve certain goals. These goals are mentioned in the various definitions of sustainable tourism. One well-known example is the definition of the WTO: "Sustainable tourism development meets the needs of present tourists and host regions while protecting and enhancing opportunity for the future. It is envisaged as leading to management of all resources in such a way that economic, social, and aesthetic needs can be fulfilled while maintaining cultural integrity, essential ecological processes, biological diversity, and life support system." [1].

In other words, sustainable tourism development is ecologically sustainable, viable as well as ethically and socially equitable. So, sustainable tour-ism integrates the natural, cultural and human environment. Therefore it respects the fragile environmental balance that characterises many tourism destinations, particularly in environmentally sensitive areas. Furthermore, it is characterised by a long term perspective. To evaluate if tourism development accomplishes these goals, a set of criteria has to be developed which serves as a frame to identify and structure the different aspects the goals of sustainable tourism are referring to [7].

\section{Community Based Tourism in Thailand}

Over the past 15 years, more than 80 Thai communities have worked to develop CBT. CBT gives guests opportunities to experience and learn about Thai life, culture and nature through fun, hands-on activities led by community guides and local host families. CBT initiatives are designed to support Thai communities by developing community members' knowledge and skills, generating income for local families, funding social and environmental projects, catalyzing community cooperation and celebrating local culture [7].

As the potential of tourism to contribute towards sustainable development is increasingly recognized in Thailand, ASEAN and globally, now is an ideal time to review the direction, successes and challenges of CBT in Thailand, so that lessons learned can benefit local communities, development practitioners and tourism industry stakeholders [5]. The community-based enterprise, particularly home stay community based tourism, is widely recognized as one of the major players in contributing to sustainable development of Thailand. Therefore, the establishment and success of the home stay community based tourism are highly needed by the Thai community.

\section{The Participation of People in Community Based Tourism Management}

According to [7] it is presented that the form and the level of participation is divided into 3 levels including:

1) Direct participation - this sort of participation people need to partake in the jungle community on their own.

2) Group participation - Normally, the jungle community will operate works together as in a form of a group or organisation. This kind of participation people will vote for finding a representative to be a committee of a group in order to execute all works associated with jungle community instead of them.

3) Participation agency - this type of participation people have an opportunity to choose the agents who have enough ability to operate works for them. On account of time limitation and being self employed person, they cannot participate in that by themselves.

\section{Methodology}

The data for this study were collected from community based tourism, Nakhon Si Thammarat, Thailand. A32 members of this Community base tourism were participated this study. The data were collected by using face-tofacewith structured questionnaire. The survey was conducted from May to June 2012.

\section{A. Population and Sample}

There are 32 members of CBT and all of them participated in this study. A total of 32 respondents comprised 5 leaders and 27 members of Community base tourism. The majority of respondents are female ranging in ages from 41 to 50 years, with a mean of age of 45.5 years. 72 percent were married. The majority $(67 \%)$ of the respondents had completed primary school and Bachelor's degree.

\section{B. Measures}

A survey questionnaire was developed to collect data for testing the validity of the model and research hypotheses. Variables in the questionnaire include managerial functions and success of community based tourism. Questions to measure managerial functions and success of community based tourism in this study provided some ranges of answer for respondents in order to avoid refusal of responses.

\section{FINDING AND ANALYSIS}

The result of the research in the table above is shown that what are the factors that have an effect on the procedures to reinforce the tourist attractions in community.

According to the table, it illustrates the level of the respondents' opinion concerned with the factors, which affect the procedures of developing community empowerment of tourist attractions. Overall, it can be seen that most factors are on moderate level. When it is considered by each factor, it is found that the highest average is Natural resources and environmental management in communities at 3.75. The second highest is Safety and security in life and assets at 3.49. Lastly, the least average is Economic issues at 3.18.

According to the focus group discussion among researchers, community leaders and representatives, guidelines on strengthening the processes of developing community empowerment of tourist attractions were suggested as related organizations both in governmental and 
private sectors and community members should participate in meetings to brainstorm ideas for managing the community tourist attractions. The systematic management should be adopted including planning, organizing, guiding and controlling in all related sections.

The private sectors should be encouraged and supported to participate in developing the tourist attractions in other matters, for example management in lodgings, restaurants, tourism activities and souvenirs, and many others

TABLE I: Mean Stand DeViation of Factors AFFeCting the PROCESS OF DEVELOPING COMMUNITY BASED TOURISM

\begin{tabular}{lccc}
\multicolumn{1}{c}{ OF DEVELOPING COMMUNITY BASED TOURISM } \\
\hline $\begin{array}{l}\text { Factors affecting the } \\
\text { processes of developing } \\
\text { community based tourism }\end{array}$ & $\bar{X}$ & S.D. & Result \\
\hline $\begin{array}{l}\text { Economic issues } \\
\text { Natural resources and } \\
\text { environmental management } \\
\text { in communities }\end{array}$ & 3.18 & .81 & Moderate \\
$\begin{array}{l}\text { Health \& Sanitation issues } \\
\text { Religions Culture and } \\
\text { tradition issues }\end{array}$ & 3.41 & .82 & Moderate \\
$\begin{array}{l}\text { Management factors } \\
\text { Safety and security in life } \\
\text { and assets }\end{array}$ & 3.22 & .97 & Moderate \\
Total & 3.49 & 1.25 & Moderate \\
\hline \hline
\end{tabular}

\section{DISCUSSION}

There are factors that affected the processes of developing community based tourism. Firstly, economic factor was at a moderate level, which harmonised with the research outcome conducted by [8]. It is found that the power of community of economic issues were a factor in terms of the cause of community, which was at the moderate level. Secondly, natural resources and environmental management in communities was high, which was in accord with [9]. In addtion, Weerapol Thongma [10], also stated that tourism considering for the sustainable environment in community, social and tradition was fixed the direction by community. In this regard, the community has the right to manage and control. Thirdly, management factor was also at a moderate level, which matched up with [9].

Moreover, Weerapol Thongma and Prajate Amnaj [10] also said that it is not easy to administer to gain the most usefulness and to make it to be sustainable. As a consequence, it is necessary for the community to have the leader who can administer tourism in community. Apart form that, the leader should be accepted by people, and also the leader should have a good idea and wide vision and well understanding of tourism.

\section{SUGGESTIONS}

Guidelines on developing community base tourism to sustainable management of tourist attractions in Nakhon $\mathrm{Si}$ Thammarat need to consider the follow:

1) The successful management of sustainable tourism must be undertaken in the form of community activities, Administration must be transparent, running under acceptable rules, subjected to assessment.

2) Find a means to distribute income and profit to the widest section of the people. Part of the income should be reserved to fund the development of the communities and for conservation of tourism resources. This will encourage people to take part in the tourism industry.

3) Develop an appropriate form of sustainable tourism. This will be achieved by encouraging wide varieties of tourism related activities, finding characteristics of communities or developing the uniqueness of the communities.

\section{ACKNOWLEDGMENT}

The authors would like to thank the Faculty of Business Administration, Rajamangala University of Technology Srivijaya, Songkla, Thailand, for supporting the time and facilities in conducting this research. Also, I would like to thank my family and my friends for their supporting.

\section{REFERENCE}

[1] B. Trac and B. Kelly, "Sustainable tourism development: the long road from theory to practice," International Journal of Economic Development, vol. 3, no. 3, pp. 1-18, 2001.

[2] B. Jitangwattana, How to Plan on Developing the Sustainable Tourism, $1^{\text {st }}$ ed., The Faculty of Humanities, Chiang Mai University.

[3] Ecological Tourism in Europe and Unesco-Bresce, Stainable tourism Training the Trainers Programme, 2009.

[4] M. G. Korres, "The role of innovation activities in tourism and regional growth In Europe," Tourismos: An International Multidisciplinary Journal of Tourism vol. 3, no. 1, pp. 135-152, 2008.

[5] D. Gracan Z. Zadel, and A. R. Lugaric, "Management of sustainable tourism development: case study plitvice lakes national park," International Journal of Management Cases, pp. 24-33, 2011.

[6] R. Butler, "Tourism - An evolutionary perspective," in Tourism and Sustainable Development: Monitoring, Planning, Managing, N. Jame and R. Butler and W. Geoffrey, (eds.), Heritage Resource Centre, University of Waterloo, 1993, pp. 27-44.

[7] U. Polpipat, "Sustainable tourism: case study of ecotourism based community in Thailand," The Journal of Tourism, vol. 12, no. 4, pp. 38-48, October-December, 2002.

[8] P. Sopana et al., "Factors regarding the cause affecting the community based tourism North Eastern villages of Thailand," Journal of Rajabhat MahaSarakham University, R.M.U., vol. 2, no. 2, pp. 63-73, May-August, 2010.

[9] W. Thongma and P. Amnaj. (2010). Community Based Tourism: CBT. [Online]. Available: http://www.dnp.go.th/fca16/file/i49xy4ghqzsh3j1.doc

[10] W. Thongma and P. Amnaj, "The impact of tourism activities arrangement toward to local people in Mae-Ram sub-district, MaeRim district, Chiang Mai," The Report of Research Outcome of Chiang Mai, Maejo University, 2004.

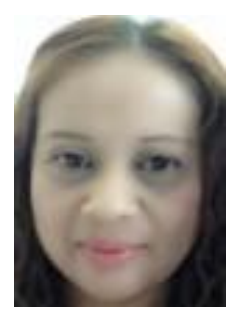

marketing.
Preechaya Chumsri was born in Songkla, Thailand on the February 6, 1968. She holds a bachelor education (BE) degree in marketing from Srinakharinwirot, Southern Campus in 1992. And master Business Administration (MBA.) degree in marketing in 2005. She is an assistant professor of Marketing, Faculty of Business Administration, Rajamangala University of Technology Srivijaya, Thailand. My areas of research interest include marketing, management, tourism and strategy 